\title{
A STATISTICAL ANALYSIS OF DIVIDEND IN CHOSEN COMPANIES LISTED ON THE WARSAW STOCK EXCHANGE
}

\author{
Małgorzata Łuniewska, Ph.D. \\ Faculty of Economics and Management \\ University of Szczecin \\ Mickiewicza 64,71-101 Szczecin \\ e-mail:maluni@poczta.fm
}

Received 31 October 2007, Accepted 18 December 2007

\begin{abstract}
The capital market appeared in Poland relatively not far ago, so it is the young market and is not shaped well. Although, the development rate does not satisfy all the believers of the capital market, it should be emphasized that this market is functioning and is developing. Market indicators are a significant element of the market analysis performed by means of fundamental analysis. The aim of this article is to study the statistic regularity in the scope of indicators connected with a dividend. In Poland dividend is not discussed often and indicators connected with dividend are practically not used in stock analysis. This study will show the usefulness of these measures in the analysis connected with investment on the stock exchange market. The analyses are conducted for some dividend variables on the Warsaw Stock Exchange (dividend rate of return and pay indicators, stopping and re-investment). The analyses concern data in the period of $2000 \div 2006$. Some statistical parameters to detect statistical regularity for dividend rate of return and pay indicators, stopping and re-investment on the Warsaw Stock Exchange are used in the paper. The author tried to analyse the relation between selected variables too. The study should make it possible to decide if measures such as dividend rate of return and pay indicators, stopping and re-investment are unquestionably important and useful in stock analysis. It is particularly important from the point of view of long-term investment, as well as the fundamental analysis. They should be included in the group of market indicators in case of statistically significant influence of measures connected with a dividend on investment profitability. This leads to the possibility of significant growth of an investment that can turn out profitable on the capital market.
\end{abstract}

Keywords: dividend, capital market, Warsaw Stock Exchange.

JEL classification: $\mathrm{C} 10$. 


\section{Introduction}

The capability of capital allocation to valuable papers has appeared along with the development of the market economy. This alternative gives the possibility to have fast and large earnings, but simultaneously is encumbered by higher risk of the capital loss. Certainly, the capability of investment is not giving desired increments. This process is more complicated and requires proper theoretical and practical preparation, so forces the investor to have the knowledge of technical, basic and portfolio analysis. The market ratios are the source of very important information on the capital market. Their role and the meaning in developed capital markets is very high, and practically their application is considerably extended (e.g. in the process of the company valuation by the income method). The usage of the market ratios by the investors on the stock exchange market is also important.

In this aspect the following are of special significance ${ }^{1}$ :

- the price earning ratio $(P / E)$;

- the price book value $(P / B V)$;

- dividend yield (DSZ).

These relations are the elements of the basic analysis, which is a most often used method in case of long-term investment. The subject of investigation in the following article is the dividend, its statistical analysis and the attempt to define its role on the Polish capital market $^{2}$.

\section{Description of Scientific Procedure}

Taking into consideration the market ratios it is apparent that recently the dividend paid by stock companies has been discussed more and more often. It is the key ratio in developed capital markets which supports the investment decisions. This ratio allows to describe the relation between a dividend and a market share price.

Its structure is as follows ${ }^{3}$ :

$$
\text { Dividend yield }=\frac{\text { dividend }}{\text { price of share }} \cdot 100
$$

In the developed markets this measure is compared to the sector norm or to the whole market. Its high amount means that a share is overvalued, the low one - that it is undervalued. The level of the stock exchange development in Poland is not high and has no significant 
meaning, but it might be used as additional information helpful in other stock analyses. It should be added that recently most Polish stock companies have started to forecast the information power of the dividend itself. However, the fact of building stable stock ownership has the most important meaning in the context of dividend, as it is happening in the developed capital markets. It also has great strategic meaning from the point of view of a company development.

A stock player, apart from the profits which might be obtained due to the changes of share prices, also considers the level of paid dividend and the return rate from the last years. Thus, it presents moderately stable revenues for them which they might use for financing new investment and consumption. The second aspect that emphasizes the meaning of the dividend in the process of an investment decision-making is the comparison of dividend yield with the interest on time deposit in banks. If the dividend yield is higher than the interest on deposit, then investors (particularly physical persons) will choose this form of investment - the purchase of company stocks that pays the dividend. Moreover, it shows that stock prices of companies which pay dividend regularly have the upward tendency on the market. The fact that appreciation of stock prices is connected with the dividend payment should not surprise anybody, because companies paying the part of generated increment to their shareholders basically enjoy good financial conditions. It is not only connected with the obtained profit, but also with the level of obtained financial ratios (liquidity, profitability or profitability) as well as the markets $(P / E, P / B V, D S Z$ - dividend yield). Certainly, there are investors who are most focused on increments that might be obtained directly from share price changes. In such case, they take into consideration the companies that reinvest their profit. The reinvestment relies on assigning its considerable part to development.

When determining a company character - if it is growing or profitable, it is important for an investor to obtain information from basic analysis: the level of financial and market ratios, the way the property is secured, adopted strategies and the direction of development, investments, their kind, the manner of management, etc. The capital profitability ratio and the verification of its level in last years is particularly important. In this context all the efforts are aimed at its maximization with the simultaneous development of the company.

In this article the author attempts to apply the following measures which make it possible to determine the character of the company ${ }^{4}$ :

- a stop ratio

$$
\mathrm{WZ}=\frac{\text { Profit }- \text { Dividend }}{\text { Profit }}
$$


- a payment ratio

$$
\mathrm{WW}=\frac{\text { Dividend per one share }}{\text { Profit per one share }},
$$

- a reinvestment ratio

$$
\begin{aligned}
& \text { WR }=\text { Capital profit } . \text { Stop return, } \\
& \text { Capital profit }=\frac{\text { increment net }}{\text { company capital }} .
\end{aligned}
$$

The high amount of the ratio (5) indicates a good financial condition. It is also the positive signal for stock investors and stockholders, because it gives the chance of higher dividend and further dynamic development of the company.

The next procedure depends on describing the amount of obtained ratios. So, if the measure (2) reaches the high level, we are entitled to say that a company is profitable. The low level is typical of a developing company. Then, the index (3) should be read vice versa. The comparison of the above mentioned relations is not the last thing to be done. The amount of the last of the presented measures (4) is significant for the correct description of the company. As it shows, it includes in its construction the capital profitability ratio and the stop ratio - the greater the first value, the more entitled we are to say that the company is growing. If the relation has the reverse character - the company is profitable. There is a rule that if the relation (2) is high, then the relation (3) is proportionally lower. Such situation results, among others, from the construction of the above mentioned examples.

In the conditions of developed market we can relate the above mentioned measures to the established sector and capital standards. These ratios are then more useful in stock analysis conducted in order to choose the most successful investment. In Poland, however, just as in the example (1) these measures still support an investment decision and should be treated rather as complementary, although their importance is still growing on the capital market. Nevertheless, these ratios should be monitored. In this way we can check how stock companies behave, what are the tendencies connected with the dividend. Such information indirectly allows the conclusion concerning the growth of the Polish capital market and about trends connected with it.

The companies that are still in the economic or technical phase of development are rather focused on investments than in profit sharing in the form of dividend among their stockholders $^{5}$. From the investor's point of view, on the one hand such situation is advantageous, because as it has already been mentioned, it can lead to increased prices of stock shares of these companies in a long-term, which can bring higher profit for the investor. 
Such a company, through its development, also has the opportunity to obtain advantageous financial results, and as it is well known has the possibility to receive profitable financial results, which obviously has a positive effect on its share prices. On the other hand, if the dividend is not paid, prospective buyers are not encouraged to invest in the company shares, which in turn results in lower share prices. Besides, in Poland the income from dividends is taxed by income tax of $19 \%$, which also discourages many investors.

\section{Statistical Analysis of Dividend in Selected Companies}

A statistic analysis of the dividend issue on the Polish capital market was carried out in selected companies listed on the Warsaw Stock Exchange. There were non-financial companies, which joined index WIG20 in March 2005. The study included years 1997-2003. On the basis of the information about the level of the dividend in thousands of PLN, net profit in thousand of PLN, the number of shares in millions and the profitability ratio of the ownership capital selected ratios were determined characterizing the problem of dividend. They were: dividend yield, a payment ratio, a reinvestment ratio and a stop ratio. In the next period the adequate descriptive statistics $x_{i}, S(x), V_{s}, M, Q, V_{Q}, A_{2}$ were calculated that allowed to present the problem synthetically. The analyses included the WIG20 companies that were treated as the most representative and the best from the economic and financial point of view. The statistical analysis conducted for such companies was an attempt to assess the Polish capital market as far as the possibility to use dividend and related ratios in the investment decision-making is concerned. On the other hand, if we assume that the selected companies are representative for the Polish capital market, we can assess the capital market and its development level. When we compare the amounts of ratios obtained by the examined companies, it was the median that was the base of reference and was regarded as normative value. The median is an important statistical measure, one of the positional measures of central tendency, which can be used when we are not interested in large deviations. It makes it possible to characterize the set of data without distortion resulting from such big differences that occur among the numerical data. The median is largely independent from extreme values (minimum and maximum) of the numbers in the studied set. However, it is not the parameter without defects so it should be used carefully.

The results of that analysis are presented successively in Tables 1-6. Table 1 shows the dividend level for the selected companies included in the study (Figures 1-2b are a graphical demonstration of the dividend level for the selected companies). The results prove that not all 
of the 14 of the analysed companies generated the profit for distribution. Moreover, the level of the dividend in all the companies was differentiated and unstable both in time (e.g. KGHM, KĘTY did not always pay the dividend) and in space (there are significant differences in dividend levels among the companies). It is also confirmed by descriptive statistics presented in Table 2 where the levels of indicated central tendency measures, an arithmetic average and a median, differ significantly (e.g. in $1999 \bar{x}=3232.36$ and $M=1644.5$ ). It should be mentioned that the arithmetic average in each of the analyzed years is almost twice as big as the median. These differences are visible in case of dispersion measures: standard $(S(x))$ and quarterly $(Q)$ deviation and the related ratios of variability. At the same time the coefficients do not stay within the interval of small variability $(0-10 \%)$ considered in the statistics as normative. Their high level indicates and confirms considerable diversity in the dividend level in the analysed companies. Some companies have very low level of a dividend, while the others - very high (e.g. in 2000 DĘBICA 39,000 PLN, and TPSA 35,838 thousand PLN). It can be connected with small profit or reluctance on the part of the companies to pay dividend. When we observe these coefficients in time we can see that they are falling slightly. However, this does not indicate that the level of the dividend is stabilizing in the analyzed companies. It should be mentioned that the dividend is an individual matter for each company and it depends not only on the generated profits or on the economic and financial level, but also on the adopted dividend policy. Yet, the determined coefficients of asymmetry $\left(A_{2}\right)$ prove that there is right-hand asymmetry of great intensity, which confirms previous conclusions.

Analyzing data in Tables 3 and 4 it can be concluded that the investigated companies belong to a developing group. It means that the companies rather re-invest a significant part of their profit. Also, the level of ratios between the companies should be recognized as stable.

In this range there are no high disparities. The information included in Table 4, where the payment ratio is an inverse of the stop ratio, should be read similarly. Yet, when deciding whether to invest in a growing or a profitable company we should pay particular attention to the level of a profitability ratio of the company capital.

It results from the analysis of data in Table 5 that the average rate of company development in the studied period oscillated around 13\%. It means that these companies were developing on the average yearly rate of 13\%. However, during the years of 1997-2003, the decreasing tendency of this measure could be observed, which might prove that the market development rate was falling. The analysis of the property profitability ratio is also very important. Then, its low value becomes an alarm signal for investors. In a reverse situation, the re-investment ratio can be used more safely when making investment decisions. 
The last of the analyzed ratios is a dividend rate (Table 6). The large differentiation among companies is seen in this area. This ratio is characterized by instability in time, as well as among companies. Comparing its level to the median as a standard measure, we can speak about overvaluing of the company shares (e.g. KETY - 4400 in 2000) or undervaluing (e.g. TPSA -0.06 in 2001).

\section{Conclusions}

Large differentiation of the levels of the analysed ratios for the selected WIG20 index companies confirms the lack of the companies' development stabilisation, even of those considered representative for the Warsaw Stock Exchange. However, it is important that the Management Boards of the companies recognise the importance of the dividend and identify with it willingly. Building stable stock ownership is advantageous from the point of view of a moderately stable company development strategy. Reinvestment of generated profits is also of a key importance. What is more, the distribution of the dividend is often tempting for the investors. The companies should take this problem into consideration and share their profits with their stockholders if possible. However, in the situations that are important for their development the companies should reinvest. Here the law of selection and advantage can be applied, both by the stockholders (to buy shares of the growing or profitable companies), and by the companies themselves (to pay or to reinvest).

Summarizing, it should be stated that the quoted measures such as the dividend rate of return and the stop, payment and reinvestment ratios are unquestionably important and useful measures. However, we must support them with the other stock analyses, particularly by the basic analysis. This is nothing but obvious, because making the right investment decision requires wider analysis, not only focusing on selected relations. Following the above mentioned recommendations is highly adequate in case of our still young capital market.

Table 1

The level of dividend in the analyzed companies in thousands of PLN

\begin{tabular}{|l|c|c|c|c|c|c|c|}
\hline \multicolumn{1}{|c|}{ Company } & 1997 & 1998 & 1999 & 2000 & 2001 & 2002 & 2003 \\
\hline AGORA & 0.0 & 1.0 & 288.0 & 10105.0 & 2809.0 & 19315.0 & 17028.0 \\
\hline CERSANIT & 0.2 & 0.0 & 0.0 & 0.0 & 0.0 & 0.0 & 0.0 \\
\hline COMPLAND & 215.2 & 415.0 & 676.0 & 2309.0 & 2202.0 & 868.0 & 3332.0 \\
\hline DEBICA & 114.0 & 3640.0 & 161.0 & 39.0 & 1.0 & 0.0 & 0.0 \\
\hline GTC & 0.0 & 0.0 & 0.0 & 0.0 & 0.0 & 916.0 & 6783.0 \\
\hline KETY & 342.3 & 0.0 & 3329.0 & 1.0 & 1819.0 & 2931.0 & 9667.0 \\
\hline KGHM & 443.0 & 33086.0 & 6889.0 & 4954.0 & 15463.0 & 4623.0 & 49012.0 \\
\hline
\end{tabular}




\begin{tabular}{|l|c|c|c|c|c|c|c|}
\hline NETIA & 0.0 & 0.0 & 0.0 & 0.0 & 0.0 & 0.0 & 0.0 \\
\hline ORBIS & 1098.0 & 1528.0 & 981.0 & 99.0 & 2436.0 & 151.0 & 1566.0 \\
\hline PROKOM & 0.0 & 277.0 & 702.0 & 136.0 & 1777.0 & 1121.0 & 6714.0 \\
\hline SOFTBANK & 0.0 & 0.0 & 77.0 & 2.0 & 1347.0 & 76.0 & 0.0 \\
\hline STALEXP & 516.0 & 273.0 & 288.0 & 178.0 & 1296.0 & 2090.0 & 1913.0 \\
\hline SWIECIE & 262.7 & 211.0 & 40.0 & 1266.0 & 14156.0 & 2441.0 & 2983.0 \\
\hline TPSA & 50787.2 & 33938.0 & 31822.0 & 35838.0 & 25187.0 & 9019.0 & 723.0 \\
\hline
\end{tabular}

Source: Notoria Serwis 1/2005.

Table 2

The basic descriptive statistics for dividends in 1997-2003

\begin{tabular}{|c|c|c|c|c|c|c|c|}
\hline Years & $\bar{x}$ & $S(x)$ & $V_{s}$ & $M$ & $Q$ & $V_{Q}$ & $A_{2}$ \\
\hline 1997 & 3841.33 & 13515.44 & 3.52 & 164.60 & 258.00 & 1.57 & 0.36 \\
\hline 1998 & 5240.64 & 12018.97 & 2.29 & 242.00 & 1820.00 & 7.52 & 0.87 \\
\hline 1999 & 3232.36 & 8444.47 & 2.61 & 288.00 & 1644.50 & 5.71 & 0.85 \\
\hline 2000 & 3923.36 & 9617.74 & 2.45 & 117.50 & 2476.50 & 21.08 & 0.95 \\
\hline 2001 & 4892.36 & 7683.27 & 1.57 & 1798.00 & 7077.50 & 3.94 & 0.75 \\
\hline 2002 & 3110.79 & 5277.68 & 1.70 & 1018.50 & 2273.50 & 2.23 & 0.59 \\
\hline 2003 & 7122.93 & 12988.15 & 1.82 & 2448.00 & 4833.50 & 1.97 & 0.49 \\
\hline
\end{tabular}

Source: own study on the basis of Table 1 .

The stop ratio for the selected companies in $1997-2003$

\begin{tabular}{|l||c|c|c|c|c|c|c|}
\hline \multicolumn{1}{|c|}{ Stop ratio } & 1997 & 1998 & 1999 & 2000 & 2001 & 2002 & 2003 \\
\hline \hline AGORA & $\mathbf{1 . 0 0 0 0}$ & $\mathbf{1 . 0 0 0 0}$ & $\mathbf{0 . 9 9 8 3}$ & 0.9430 & 0.9730 & 0.7050 & 0.0000 \\
CERSANIT & $\mathbf{1 . 0 0 0 0}$ & $\mathbf{1 . 0 0 0 0}$ & $\mathbf{1 . 0 0 0 0}$ & $\mathbf{1 . 0 0 0 0}$ & $\mathbf{1 . 0 0 0 0}$ & $\mathbf{1 . 0 0 0 0}$ & $\mathbf{1 . 0 0 0 0}$ \\
\hline COMPLAND & 0.9870 & 0.9807 & 0.9748 & 0.9384 & 0.9493 & 0.9661 & 0.8784 \\
\hline DEBICA & 0.9985 & 0.9590 & 0.9978 & $\mathbf{0 . 9 9 9 4}$ & $\mathbf{1 . 0 0 0 0}$ & $\mathbf{1 . 0 0 0 0}$ & $\mathbf{1 . 0 0 0 0}$ \\
\hline GTC & $\mathbf{1 . 0 0 0 0}$ & $\mathbf{1 . 0 0 0 0}$ & $\mathbf{1 . 0 0 0 0}$ & $\mathbf{1 . 0 0 0 0}$ & $\mathbf{1 . 0 0 0 0}$ & 0.9033 & 0.0000 \\
\hline KETY & 0.9925 & $\mathbf{1 . 0 0 0 0}$ & 0.9387 & $\mathbf{1 . 0 0 0 0}$ & 0.9120 & 0.9168 & 0.7180 \\
\hline KGHM & $\mathbf{0 . 9 9 9 5}$ & 0.8425 & 0.9529 & 0.9940 & $\mathbf{1 . 1 8 8 3}$ & 0.9627 & 0.8631 \\
\hline NETIA & $\mathbf{1 . 0 0 0 0}$ & $\mathbf{1 . 0 0 0 0}$ & $\mathbf{1 . 0 0 0 0}$ & $\mathbf{1 . 0 0 0 0}$ & $\mathbf{1 . 0 0 0 0}$ & $\mathbf{1 . 0 0 0 0}$ & $\mathbf{1 . 0 0 0 0}$ \\
\hline ORBIS & 0.9821 & 0.9787 & 0.9909 & 0.9990 & 0.9493 & $\mathbf{0 . 9 9 3 4}$ & 0.9671 \\
\hline PROKOM & $\mathbf{1 . 0 0 0 0}$ & $\mathbf{0 . 9 9 6 1}$ & 0.9941 & 0.9986 & 0.9859 & 0.9930 & 0.9368 \\
\hline SOFTBANK & $\mathbf{1 . 0 0 0 0}$ & $\mathbf{1 . 0 0 0 0}$ & $\mathbf{0 . 9 9 8 9}$ & $\mathbf{1 . 0 0 0 0}$ & 0.9242 & $\mathbf{1 . 0 0 3 6}$ & $\mathbf{1 . 0 0 0 0}$ \\
\hline STALEXP & 0.9929 & 0.9949 & $\mathbf{1 . 0 0 9 9}$ & $\mathbf{1 . 0 0 0 5}$ & $\mathbf{0 . 9 8 6 4}$ & $\mathbf{1 . 0 1 0 4}$ & $\mathbf{0 . 9 7 5 9}$ \\
\hline SWIECIE & 0.9964 & $\mathbf{0 . 9 9 6}$ & $\mathbf{0 . 9 9 9 6}$ & 0.9952 & 0.9230 & 0.9890 & 0.9885 \\
\hline TPSA & 0.9800 & 0.9871 & 0.9898 & 0.9902 & $\mathbf{0 . 9 8 9 8}$ & $\mathbf{0 . 9 9 7 0}$ & $\mathbf{0 . 9 9 9 7}$ \\
\hline \multicolumn{1}{|c||}{ M } & $\mathbf{0 . 9 9 9 0}$ & $\mathbf{0 . 9 9 6 0}$ & $\mathbf{0 . 9 9 8 1}$ & $\mathbf{0 . 9 9 9 2}$ & $\mathbf{0 . 9 8 6 2}$ & $\mathbf{0 . 9 9 3 2}$ & $\mathbf{0 . 9 7 1 5}$ \\
\hline
\end{tabular}

Source: own study on the basis of Notoria Serwis 1/2005.

Table 3

The payment ratio for the selected companies in $1997-2003$
\begin{tabular}{|l||c|c|c|c|c|c|c|}
\hline Payment ratio & 1997 & 1998 & 1999 & 2000 & 2001 & 2002 & 2003 \\
\hline \hline AGORA & 0.0000 & 0.0000 & 0.0017 & $\mathbf{0 . 0 5 7 0}$ & $\mathbf{0 . 0 2 7 0}$ & $\mathbf{0 . 2 9 5 0}$ & $\mathbf{4 . 4 8 1 1}$ \\
\hline CERSANIT & 0.0000 & 0.0000 & 0.0000 & 0.0000 & 0.0000 & 0.0000 & 0.0000 \\
\hline COMPLAND & $\mathbf{0 . 0 1 3 0}$ & $\mathbf{0 . 0 1 9 3}$ & $\mathbf{0 . 0 2 5 2}$ & $\mathbf{0 . 0 6 1 6}$ & $\mathbf{0 . 0 5 0 7}$ & $\mathbf{0 . 0 3 3 9}$ & $\mathbf{0 . 1 2 1 6}$ \\
\hline DEBICA & $\mathbf{0 . 0 0 1 5}$ & $\mathbf{0 . 0 4 1 0}$ & $\mathbf{0 . 0 0 2 2}$ & 0.0006 & 0.0000 & 0.0000 & 0.0000 \\
\hline
\end{tabular}

Table 4 


\begin{tabular}{|l||c|c|c|c|c|c|c|}
\hline GTC & 0.0000 & 0.0000 & 0.0000 & 0.0000 & 0.0000 & $\mathbf{0 . 0 9 6 7}$ & $\mathbf{2 . 6 5 5 8}$ \\
\hline KETY & $\mathbf{0 . 0 0 7 5}$ & 0.0000 & $\mathbf{0 . 0 6 1 3}$ & 0.0000 & $\mathbf{0 . 0 8 8 0}$ & $\mathbf{0 . 0 8 3 2}$ & $\mathbf{0 . 2 8 2 0}$ \\
\hline KGHM & 0.0005 & $\mathbf{0 . 1 5 7 5}$ & $\mathbf{0 . 0 4 7 1}$ & $\mathbf{0 . 0 0 6 0}$ & 0.0000 & $\mathbf{0 . 0 3 7 3}$ & $\mathbf{0 . 1 3 6 9}$ \\
\hline NETIA & 0.0000 & 0.0000 & 0.0000 & 0.0000 & 0.0000 & 0.0000 & 0.0000 \\
\hline ORBIS & $\mathbf{0 . 0 1 7 9}$ & $\mathbf{0 . 0 2 1 3}$ & $\mathbf{0 . 0 0 9 1}$ & $\mathbf{0 . 0 0 1 0}$ & $\mathbf{0 . 0 5 0 7}$ & 0.0066 & $\mathbf{0 . 0 3 2 9}$ \\
\hline PROKOM & 0.0000 & $\mathbf{0 . 0 0 4}$ & $\mathbf{0 . 0 0 5 9}$ & $\mathbf{0 . 0 0 1 4}$ & $\mathbf{0 . 0 1 4 1}$ & $\mathbf{0 . 0 0 7 0}$ & $\mathbf{0 . 0 6 3 2}$ \\
\hline SOFTBANK & 0.0000 & 0.0000 & 0.0011 & 0.0000 & $\mathbf{0 . 0 7 5 8}$ & 0.0000 & 0.0000 \\
\hline STALEXP & $\mathbf{0 . 0 0 7 1}$ & $\mathbf{0 . 0 0 5 1}$ & 0.0000 & 0.0000 & 0.0136 & 0.0000 & 0.0241 \\
\hline SWIECIE & $\mathbf{0 . 0 0 3 6}$ & $\mathbf{0 . 0 0 4 1}$ & 0.0004 & 0.0048 & $\mathbf{0 . 0 7 7 0}$ & $\mathbf{0 . 0 1 1 0}$ & 0.0115 \\
\hline TPSA & $\mathbf{0 . 0 2 0 0}$ & $\mathbf{0 . 0 1 2 9}$ & $\mathbf{0 . 0 1 0 2}$ & $\mathbf{0 . 0 0 9 8}$ & 0.0102 & 0.0030 & 0.0003 \\
\hline \multicolumn{1}{|c||}{ M } & $\mathbf{0 . 0 0 1 0}$ & $\mathbf{0 . 0 0 4 0}$ & $\mathbf{0 . 0 0 1 9}$ & $\mathbf{0 . 0 0 0 8}$ & $\mathbf{0 . 0 1 3 8}$ & $\mathbf{0 . 0 0 6 8}$ & $\mathbf{0 . 0 2 8 5}$ \\
\hline
\end{tabular}

Source: own study on the basis of Notoria Serwis 1/2005.

Table 5

The reinvestment ratio for the selected companies in $1997-2003$

\begin{tabular}{|l||c|c|c|c|c|c|c|}
\hline $\begin{array}{c}\text { Reinvestment } \\
\text { ratio }\end{array}$ & 1997 & 1998 & 1999 & 2000 & 2001 & 2002 & 2003 \\
\hline \hline AGORA & $\mathbf{4 1 . 7 4 \%}$ & $\mathbf{2 2 . 9 9 \%}$ & $\mathbf{1 8 . 5 3 \%}$ & $\mathbf{1 7 . 0 4 \%}$ & $\mathbf{1 6 . 7 8 \%}$ & $4.97 \%$ & $0.00 \%$ \\
\hline CERSANIT & $\mathbf{3 3 . 9 0 \%}$ & $\mathbf{2 4 . 2 6 \%}$ & $\mathbf{1 8 . 0 2 \%}$ & $\mathbf{2 8 . 4 4 \%}$ & $3.29 \%$ & $0.28 \%$ & $1.13 \%$ \\
\hline COMPLAND & $14.12 \%$ & $14.92 \%$ & $\mathbf{1 7 . 5 5 \%}$ & $\mathbf{1 9 . 8 6 \%}$ & $\mathbf{1 9 . 0 6 \%}$ & $6.83 \%$ & $5.61 \%$ \\
\hline DEBICA & $\mathbf{1 5 . 1 7 \%}$ & $14.86 \%$ & $11.53 \%$ & $8.41 \%$ & $1.31 \%$ & $\mathbf{1 2 . 4 2 \%}$ & $\mathbf{1 6 . 5 8 \%}$ \\
\hline GTC & $0.00 \%$ & $\mathbf{3 9 . 6 3 \%}$ & $0.00 \%$ & $\mathbf{2 9 . 1 2 \%}$ & $\mathbf{2 2 . 3 1 \%}$ & $\mathbf{1 0 . 2 4 \%}$ & $0.00 \%$ \\
\hline KETY & $14.17 \%$ & $14.81 \%$ & $13.72 \%$ & $3.51 \%$ & $3.52 \%$ & $6.84 \%$ & $\mathbf{9 . 1 1 \%}$ \\
\hline KGHM & $12.47 \%$ & $3.68 \%$ & $0.00 \%$ & $15.10 \%$ & $0.00 \%$ & $6.11 \%$ & $8.87 \%$ \\
\hline NETIA & $0.00 \%$ & $0.00 \%$ & $0.00 \%$ & $0.00 \%$ & $0.00 \%$ & $0.00 \%$ & $2.05 \%$ \\
\hline ORBIS & $5.32 \%$ & $7.82 \%$ & $9.35 \%$ & $8.08 \%$ & $4.17 \%$ & $2.64 \%$ & $3.60 \%$ \\
\hline PROKOM & $\mathbf{1 5 . 8 4 \%}$ & $\mathbf{1 8 . 4 1 \%}$ & $\mathbf{2 1 . 8 0 \%}$ & $\mathbf{2 2 . 8 2 \%}$ & $7.46 \%$ & $\mathbf{1 7 . 8 1 \%}$ & $0.55 \%$ \\
\hline SOFTBANK & $\mathbf{4 1 . 6 4 \%}$ & $\mathbf{2 6 . 8 8 \%}$ & $\mathbf{2 8 . 3 4 \%}$ & $14.18 \%$ & $3.72 \%$ & $0.00 \%$ & $0.00 \%$ \\
\hline STALEXP & $6.83 \%$ & $3.62 \%$ & $\mathbf{3 1 . 0 6 \%}$ & $0.00 \%$ & $0.00 \%$ & $0.00 \%$ & $0.00 \%$ \\
\hline SWIECIE & $7.12 \%$ & $5.72 \%$ & $10.56 \%$ & $\mathbf{2 2 . 1 4 \%}$ & $\mathbf{1 8 . 9 5 \%}$ & $\mathbf{2 0 . 5 0 \%}$ & $\mathbf{2 1 . 4 3 \%}$ \\
\hline TPSA & $11.34 \%$ & $10.79 \%$ & $10.59 \%$ & $15.32 \%$ & $7.29 \%$ & $7.12 \%$ & $5.27 \%$ \\
\hline \multicolumn{1}{|c|}{ M } & $\mathbf{1 4 . 1 7 \%}$ & $\mathbf{1 5 . 7 5 \%}$ & $\mathbf{1 7 . 5 5 \%}$ & $\mathbf{1 7 . 0 4 \%}$ & $\mathbf{7 . 7 0 \%}$ & $\mathbf{9 . 6 7 \%}$ & $\mathbf{9 . 1 1 \%}$ \\
\hline
\end{tabular}

Source: own study on the basis of Notoria Serwis 1/2005.

The dividend yield for the selected companies in 1997-2003

\begin{tabular}{|l||c|c|c|c|c|c|c|}
\hline \multicolumn{1}{|c|}{ Company } & 1997 & 1998 & 1999 & 2000 & 2001 & 2002 & 2003 \\
\hline \hline AGORA & & 0.00 & 20.97 & 0.84 & 1.82 & 0.25 & 0.30 \\
\hline CERSANIT & 0.00 & & & & & & \\
\hline COMPLAND & 26.95 & 10.36 & 10.07 & 4.96 & 4.77 & 10.46 & 2.73 \\
\hline DEBICA & 77.19 & 1.43 & 27.76 & 87.18 & 3190.00 & & \\
\hline GTC & & & & & & 0.00 & 0.00 \\
\hline KETY & 15.78 & & 1.68 & 4400.00 & 2.54 & 1.73 & 1.40 \\
\hline KGHM & 2.93 & 0.04 & 0.38 & 0.52 & 0.08 & 0.29 & 0.05 \\
\hline NETIA & & & & & & & \\
\hline ORBIS & 1.62 & 1.81 & 3.80 & 26.16 & 0.72 & 11.19 & 1.77 \\
\hline PROKOM & & 48.74 & 18.52 & 127.94 & 5.97 & 11.33 & 2.59 \\
\hline SOFTBANK & & & 181.17 & 3250.00 & 1.68 & 14.67 & \\
\hline STALEXP & 4.67 & 7.11 & 9.65 & 9.94 & 0.22 & 0.06 & 0.09 \\
\hline SWIECIE & 6.81 & 4.08 & 40.88 & 1.74 & 0.20 & 1.51 & 2.59 \\
\hline
\end{tabular}

Table 6 


\begin{tabular}{|c||c|c|c|c|c|c|c|}
\hline \multicolumn{1}{|l||}{ TPSA } & 0.00 & 0.05 & 0.09 & 0.08 & 0.06 & 0.14 & 2.10 \\
\hline $\boldsymbol{M}$ & $\mathbf{4 . 6 7}$ & $\mathbf{1 . 8 1}$ & $\mathbf{1 0 . 0 7}$ & $\mathbf{9 . 9 4}$ & $\mathbf{1 . 6 8}$ & $\mathbf{1 . 5 1}$ & $\mathbf{1 . 5 8}$ \\
\hline $\bar{x}$ & $\mathbf{1 5 . 1 1}$ & $\mathbf{8 . 1 8}$ & $\mathbf{2 8 . 6 3}$ & $\mathbf{7 1 9 . 0 3}$ & $\mathbf{2 9 1 . 6 4}$ & $\mathbf{4 . 7 0}$ & $\mathbf{1 . 3 6}$ \\
\hline
\end{tabular}

Source: own study on the basis of Notoria Serwis 1/2005.

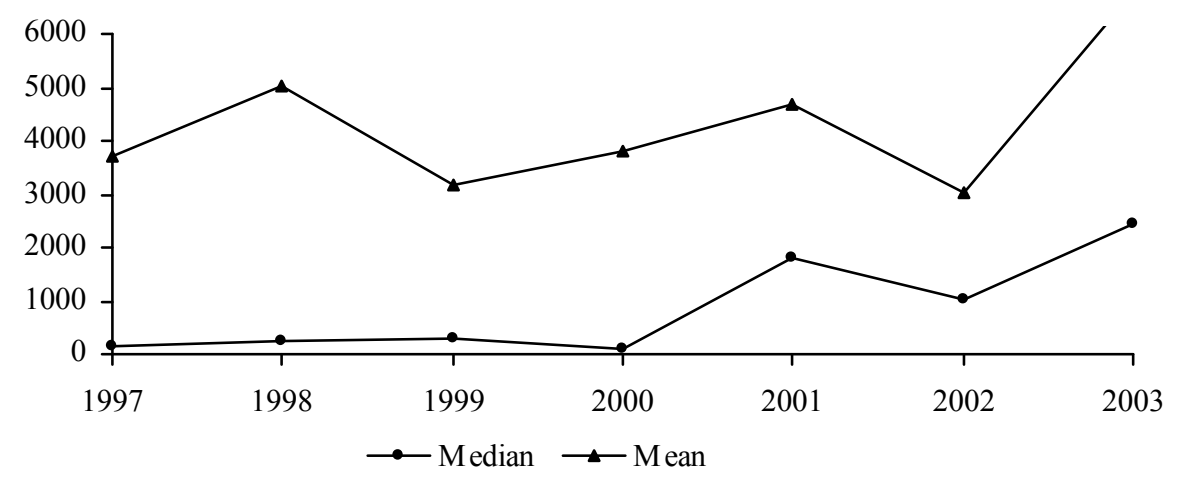

Fig. 1. The median and the mean of the dividend for the studied companies in 1997-2003 [thousands of PLN]

Source: own study.

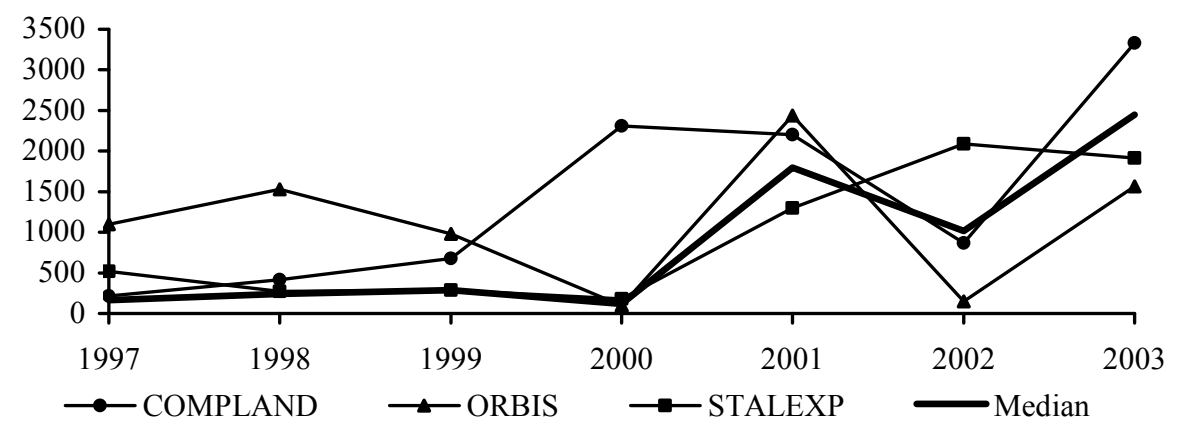

Figure 2a. The dividend for selected companies in 1997-2003 [thousands of PLN] Source: own study.

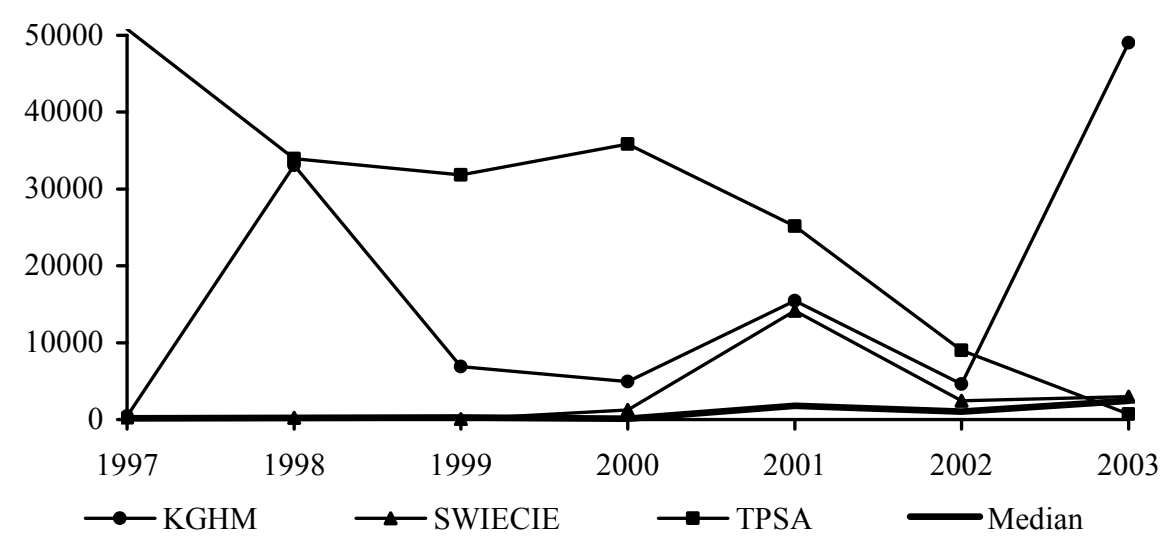

Figure 2b. The dividend for selected companies in 1997-2003 [thousands of PLN] Source: own study. 


\section{Notes}

${ }^{1}$ Market ratios are shown e.g. in the work of Tarczyński (2001).

${ }^{2}$ The essence of dividend in the company is presented e.g. in Sierpińska et al. (1993), Rutkowski (2000).

${ }^{3}$ See Socha (1999), p.118.

${ }^{4}$ See Socha (1999), p.120.

${ }^{5}$ The dividend policy of a company is shown e.g. in Dobbins et al. (1992), pp.140 and next.

\section{References}

Dobbins, R., Frąckowiak, W. \& Witt, S.F. (1992). Praktyczne zarzadzanie kapitałami firmy. Poznań: PAANPOL.

Rutkowski, A. (2000). Zarządzanie finansami. Warszawa: PWE.

Sierpińska, M. \& Jachna, T. (1993). Ocena przedsiębiorstwa wedtug standardów światowych. Warszawa: PWN.

Socha, J. (1999). Zrozumieć Giełdę. Warszawa: Wydawnictwo Olympus.

Tarczyński, W. (2001). Rynki kapitałowe: metody ilościowe. Vol.1, Warszawa: Placet. 